\title{
Effect of storage conditions on post planting water status and performance of Pinus radiata D. Don stock-types
}

\author{
Amaia MenA-Petite ${ }^{\mathrm{a}}$, José María EstaviLlo ${ }^{\mathrm{a}}$, Miren DuÑABeitia ${ }^{\mathrm{a}}$, Begoña GonzÁlez-Moro ${ }^{\mathrm{a}}$, \\ Alberto MUÑOZ-RUEDA ${ }^{\text {a*}}$, Maite LACUESTA ${ }^{\text {b }}$ \\ a Departamento de Biología Vegetal y Ecología, Facultad de Ciencia y Tecnología, Universidad del País Vasco/EHU, Apdo. 644, 48080 Bilbao, Spain \\ b Departamento de Biología Vegetal y Ecología, Facultad de Farmacia, Universidad del País Vasco/EHU, Apdo. 450, 01080 Vitoria, Spain
}

(Received 7 April 2003; accepted 12 January 2004)

\begin{abstract}
We examined the post-planting effect of storage on the plant quality and initial survival potential of bare-root (BR) and soil-plugged root (PR) of radiata pine seedlings outplanted in wet and dry soils. Seedlings were subjected to planting shock even under well-watered conditions. Although the transpiration rate declined, indicating closure of stomata, water stress occurred as evidenced by the decline in relative water content (RWC) and in the leaf water potential. More than $80 \%$ of the PR seedlings and only $20 \%$ of BR seedlings transplanted in wellwatered regimen survived. Regardless of storage conditions and duration, seedlings planted under water shortage with a RWC $<50 \%$ did not survive. According to these results, it is not advisable to store radiata pine seedlings for more than 1 week when planting is under drought conditions even if the seedlings have soil around roots (PR seedlings).
\end{abstract}

container-grown / drought / field performance / seedling survival / transplanting stress

Résumé - Effet des conditions de stockage sur l'état hydrique et l'établissement de plantules de Pinus radiata D. Don avec motte et à racines nues. L'étude a porté sur l'effet du stockage sur la qualité du plant et sur les potentialités de survie initiale de plantules de Pinus radiata $\mathrm{D}$. Don à racine nue (BR) et avec motte (PR), replantées dans des sols humides et secs. Les plantules ont subi un stress de transplantation, même dans des conditions hydriques optimales. Malgré la diminution de la transpiration, signe d'une fermeture stomatique, un stress hydrique est intervenu, comme en témoigne la baisse tant du contenu hydrique relatif (RWC) que du potentiel hydrique. Plus de $80 \%$ des plantules PR et uniquement $20 \%$ des plantules BR ont survécu à leur transplantation dans des conditions hydriques optimales. Indépendamment des conditions de stockage et de la durée de celui-ci, les plantules mises en place sous déficit hydrique, avec un RWC inférieur à $50 \%$, n'ont pas survécu. Conformément à ces résultats, le stockage de plantules de Pinus radiata pour des périodes supérieures à une semaine est déconseillé lorsque la transplantation se fait sous déficit hydrique, même lorsqu'il s'agit de plantules avec motte (PR).

croissance en conteneur / établissement / sécheresse / stress de transplantation / survie

\section{INTRODUCTION}

Radiata pine is widely distributed in Northern Spain, particularly in the Basque Country where it occupies more than 150000 ha. Plantations are established by planting out nurserygrown seedlings. In nurseries that grow radiata pine seedlings are normally lifted in February and planted either immediately or after a brief storage period at temperatures between $4-10^{\circ} \mathrm{C}$ [29]. Although ideally the time between radiata pine lifting and planting should not exceed $48 \mathrm{~h}$ [1], cold storage of forest planting stock is nowadays widely accepted. In previous papers we investigated the effect of storage conditions such as temperature, duration and root coverage, on the physiology of the seedlings as well as the impact on their functional integrity and initial survival potential $[29,30]$. Our findings showed that storage caused seedling desiccation which, in turn, provoked a decrease in seedling health and an increase of electrolyte leakage, indicating membrane damage [29]. At the same time, photosynthesis was reduced as a consequence of both stomatal and non-stomatal effects [30]. Consequently, the ability of radiata pine seedlings to initiate and elongate new roots was endangered. However, the effect depended on both the storage temperature and duration and on root coverage, with the effect being more pronounced in bare-root than in containerized seedlings. In addition, we observed a correlation between post-planting survival and post-storage water potential, and between electrolyte conductivity and photosynthetic rate before planting. However, these analyses were conducted under optimum post-planting

\footnotetext{
* Corresponding author: gvpmurua@lg.ehu.es
} 
conditions that are rarely associated with reforestation sites. Accordingly, attributes measured under these controlled conditions do not provide fully reliable information about field performance of seedlings [11].

It commonly happens that just after planting on a reforestation site, seedlings are exposed to a number of stresses. The main stressful factor is commonly water stress because root confinement, poor root-soil contact and low root system permeability can limit water uptake from the soil necessary to compensate the transpiration rates $[6,20,25]$. Thus, under drought conditions seedling water stress is caused by limited water uptake from the soil $[4,14,21,39]$ and by inadequate stomatal control as evaporative demand increases [14, 21]. Consequently, it is necessary to assess the success of field performance of the conifer seedlings established not only under optimum conditions but also when the inherent performance potential of the seedlings may be altered by planting site environmental conditions [11].

The main objective of this study is to determine the extent to which variations in storage duration (1, 8 or 15 days), temperature $\left(4^{\circ} \mathrm{C}\right.$ or $\left.10{ }^{\circ} \mathrm{C}\right)$, and seedling type (PR: soil-plugged rooted seedlings or BR: bare-rooted seedlings) affect the physiology and survival of seedlings after planting. We analyse radiata pine seedling water relation patterns in response to drought and water supply regimes during the first days after planting. Finally, we relate transplanting shock with survival of the radiata pine seedlings.

\section{MATERIALS AND METHODS}

\subsection{Seedling lifting and cold storage}

Plants were raised in the Oihanberri nursery, in the Basque Country (Northern Spain). Certified seeds (OIHAN genetic type) were sown in the spring of 1995, 1996 and 1997, and grown in the soil (barerooted seedlings). Root system was repicated 1 month before lifting, and 9-month-old seedlings were lifted in February 1996, 1997 and 1998. Seedlings from each treatment were then placed in several opaque, unsealed polyethylene bags and immediately taken to the storage chambers. The bags were not sealed in order to maintain the same conditions (temperature and relative humidity) inside the bags and the storage chambers.

Plants were stored as two stock types. One type had roots surrounded by soil from the Oihanberri nursery (soil-plugged seedlings, PR), while the other had roots free of soil after washing with water (bare-rooted seedlings, BR). Both stock types were stored in controlled temperature and humidity dark chambers for 1,8 or 15 days at $4{ }^{\circ} \mathrm{C}$ or $10^{\circ} \mathrm{C}$ and at relative humidity of $80 \%$ [29]. At least, 180 seedlings per year were stored $\left[4\right.$ treatments $\left(4^{\circ} \mathrm{CPR}, 10^{\circ} \mathrm{C} \mathrm{PR}, 4^{\circ} \mathrm{C} \mathrm{BR}, 10^{\circ} \mathrm{C}\right.$ $\mathrm{BR}) \times 15$ seedlings per treatment $\times 3$ days of storage $(1,8$ and 15$)$ ]. As each measured physiological parameter remained statisticaly no different from year to year, we pooled all measures of the three years.

\subsection{Post-storage planting}

Seedlings were transferred to PVC containers (GODET 430, Pépinière Robin, France), containing a mixture of peat moss and vermiculite $1: 1(\mathrm{v} / \mathrm{v})$ previously autoclaved [27] after removal from one, eight or fifteen days of cold storage. For post-planting shock analysis, seedlings were grown in a growth chamber for twenty-six days. Growth chamber conditions were: $14 \mathrm{~h}$ day length supplied by fluo- rescent (Sylvania F48T12 SHO/VHO, Sylvania USA) and incandescent lamps, the light intensity being $400 \mu \mathrm{mol} \mathrm{m} \mathrm{m}^{-2} \mathrm{~s}^{-1}$, and $10 \mathrm{~h}$ of darkness with an average temperature of $25 / 20{ }^{\circ} \mathrm{C}$ and relative humidity of 60/80\% day/night.

Post-planting survival potential was followed for 8 weeks, as a minimum. Briefly, seedlings were grown for 2 months in a glasshouse. Light conditions were $12 \mathrm{~h}$ of sunlight, supplemented with warmwhite fluorescent lamps (Osram L85 W/31) and incandescent bulbs. Temperatures were $25 / 18{ }^{\circ} \mathrm{C}$ day/night and $50 / 70 \%$ relative humidity (RH). Seedlings were watered twice weekly with deionized water and fertilized every 15 days with nutrient solution (mg per plant): $3.65 \mathrm{~N}$, $1.29 \mathrm{P}, 3.87 \mathrm{~K}, 0.35 \mathrm{Fe}, 0.07 \mathrm{Mg}, 0.06 \mathrm{Ca}, 0.06 \mathrm{~B}, 0.01 \mathrm{Mo}$ and 0.01 $\mathrm{Zn}[27,28]$.

To simulate drought conditions one half of the plants were submitted to drought regime and the remaining half were watered three times a week until field capacity. The drought treatment was imposed by withholding water for 20 days, and then the plants were rewatered and grown in growth chamber until the end of the study. Physiological parameters were determined at one, eight and twenty days in watered and droughted plants, and at 6 days after rewatering.

\subsection{Measurement techniques}

Plant water relations parameters were determined basically as described by Mena-Petite et al. [29]. This involved measuring predawn xylem water potential $\left(\Psi_{\mathrm{w}}\right)$ using a pressure chamber [37].

Relative water content (RWC) was determined on needles using the equation $\mathrm{RWC}=100[(\mathrm{FW}-\mathrm{DW}) /(\mathrm{TW}-\mathrm{DW})]$. Five to ten needles per treatment were excised and the fresh weight $(\mathrm{FW})$ was determined. Needle turgid weight (TW) was calculated by placing needles in darkness for $24 \mathrm{~h}$ in vials containing water to allow complete rehydration. Afterwards, the needles were dried at $80^{\circ} \mathrm{C}$ for $48 \mathrm{~h}$ and dry weight (DW) was determined.

Electrolyte leakage from roots was determined using the technique described by McKay [24]. Briefly, needles or roots were washed in deionized water to remove ions and cut into $2 \mathrm{~cm}$ length pieces and put in $25 \mathrm{~mL}$-glass bottles containing $16 \mathrm{~mL}$ distilled water of known conductivity. The bottles were capped, shaken, and left at room temperature for $24 \mathrm{~h}$, then shaken again, and the conductivity of the bath solution was measured using a conductivity meter 1480-90 electrode (Cole-Palmer Instruments Co; Chicago, Il, USA). Finally, samples were killed by autoclaving at $110{ }^{\circ} \mathrm{C}$ for $10 \mathrm{~min}$, cooled to room temperature and total conductivity was recorded. The 24-h conductivity was expressed as a percentage of the conductivity value after autoclaving, having first subtracted the known conductivity value of the distilled water [27].

Root growth potential (RGP) was determined by measuring the number and root length of white roots that developed 28 days [41] after transplanting from cold storage [15]. The number of new roots $>1 \mathrm{~cm}$ produced during the test period was indexed according to the Burdett [5] scale, except that the maximum scale value was increased to 7 as proposed by Tanaka et al. [41]: 0 if no new roots, 1 if several roots but smaller than $1 \mathrm{~cm}, 2$ if $1-3$ new roots longer than $1 \mathrm{~cm}, 3$ if $4-10$, 4 if $11-30,5$ if $31-100,6$ if $101-300$, and 7 for more than 300 .

Survival was determined by assessing the percentage of plants that were alive two months after planting.

\subsection{Statistical analysis}

Statistical analysis was carried out by Fisher's PSLD method of analysis of variance (ANOVA) in the Statview 4.02 system. Significance levels quoted are at $P<0.05$. ANOVA was used to determined the effects of storage duration, root system condition and planting-time water availability on $\Psi_{\mathrm{W}}$, conductivity and survival after planting. The 
Table I. Effect of storage conditions: temperature $\left(4{ }^{\circ} \mathrm{C}\right.$ or $\left.10{ }^{\circ} \mathrm{C}\right)$, duration ( 1 or 15 days) and stock type (PR or BR) on water potential ( $\left.\Psi_{\mathrm{W}}\right)$, relative water content (RWC), transpiration (E), water use efficiency (WUE), index of root growth (IRG), and conductivity: needles electrolyte leakage (NEL) or root electrolyte leakage (REL), at planting time. Values are means \pm SE. On each line, mean values not sharing common letters are significantly different $(P<0.05)$

\begin{tabular}{|c|c|c|c|c|c|c|c|c|}
\hline \multirow{3}{*}{$\begin{array}{l}\text { Stock type } \\
\text { Storage duration } \\
\text { Storage } \\
\text { temperature }\end{array}$} & \multicolumn{4}{|c|}{ Soil-plugged root (PR) } & \multicolumn{4}{|c|}{ Bare-root (BR) } \\
\hline & \multicolumn{2}{|c|}{1 day } & \multicolumn{2}{|c|}{15 days } & \multicolumn{2}{|c|}{1 day } & \multicolumn{2}{|c|}{15 days } \\
\hline & $4^{\circ} \mathrm{C}$ & $10{ }^{\circ} \mathrm{C}$ & $4^{\circ} \mathrm{C}$ & $10{ }^{\circ} \mathrm{C}$ & $4^{\circ} \mathrm{C}$ & $10{ }^{\circ} \mathrm{C}$ & $4^{\circ} \mathrm{C}$ & $10{ }^{\circ} \mathrm{C}$ \\
\hline$\Psi_{\mathrm{W}}(\mathrm{MPa})$ & $-0.58 \pm 0.02 \mathrm{a}$ & $-0.56 \pm 0.95 \mathrm{a}$ & $-1.30 \pm 0.22 b$ & $-1.45 \pm 0.14 \mathrm{~b}$ & $-0.75 \pm 0.14 \mathrm{a}$ & $-1.12 \pm 0.08 b$ & $-1.97 \pm 0.10 \mathrm{~b}$ & $-2.48 \pm 0.02 c$ \\
\hline RWC (\%) & $89.71 \pm 0.69 a$ & $87.49 \pm 1.45 \mathrm{a}$ & $84.63 \pm 0.90 b$ & $81.85 \pm 3.90 \mathrm{~b}$ & $90.18 \pm 1.67 \mathrm{a}$ & $86.94 \pm 1.01 \mathrm{a}$ & $72.45 \pm 1.30 \mathrm{~b}$ & $58.31 \pm 2.60 \mathrm{c}$ \\
\hline $\operatorname{NEL}(\%)$ & $8.38 \pm 0.20 \mathrm{a}$ & $9.50 \pm 0.20 \mathrm{a}$ & $11.34 \pm 1.40 \mathrm{c}$ & $17.83 \pm 1.10 \mathrm{a}$ & $9.23 \pm 0.50 \mathrm{a}$ & $8.25 \pm 0.40 \mathrm{a}$ & $15.64 \pm 1.60 \mathrm{ab}$ & $28.81 \pm 1.60 \mathrm{c}$ \\
\hline $\operatorname{REL}(\%)$ & $30.91 \pm 0.90 \mathrm{a}$ & $32.11 \pm 1.10 \mathrm{a}$ & $31.67 \pm 3.90 \mathrm{a}$ & $35.09 \pm 3.60 \mathrm{a}$ & $33.93 \pm 1.00 \mathrm{a}$ & $31.83 \pm 1.90 \mathrm{a}$ & $43.02 \pm 5.00 \mathrm{~b}$ & $44.90 \pm 2.70 \mathrm{c}$ \\
\hline IRG & $5.16 \pm 0.72 \mathrm{a}$ & $5.13 \pm 0.50 \mathrm{a}$ & $4.20 \pm 0.56 b$ & $3.00 \pm 0.30 \mathrm{c}$ & $4.20 \pm 0.30 \mathrm{~b}$ & $3.00 \pm 0.00 \mathrm{c}$ & $3.00 \pm 0.00 \mathrm{c}$ & $2.00 \pm 0.00 \mathrm{~d}$ \\
\hline $\mathrm{E}\left(\mathrm{mmol} \mathrm{m} \mathrm{m}^{-2} \mathrm{~s}^{-1}\right)$ & $2.81 \pm 0.14 \mathrm{a}$ & $2.26 \pm 0.14 b$ & $2.06 \pm 0.11 \mathrm{a}$ & $1.65 \pm 0.16 b$ & $2.27 \pm 0.12 b$ & $2.02 \pm 0.11 b$ & $1.36 \pm 0.09 \mathrm{~d}$ & $1.18 \pm 0.15 \mathrm{~d}$ \\
\hline WUE $\left(\mu \mathrm{molmol}^{-1}\right)$ & $2.68 \pm 0.24 a$ & $1.84 \pm 0.24 b$ & $1.51 \pm 0.43 b$ & $1.53 \pm 0.25 \mathrm{c}$ & $3.14 \pm 0.41 \mathrm{a}$ & $2.28 \pm 0.11 b$ & $1.07 \pm 0.11 \mathrm{c}$ & $0.88 \pm 0.24 \mathrm{~d}$ \\
\hline
\end{tabular}

data present in Figures 2, 5 and 7 were tested for linear, logaritmic, exponential, and second-order polynomial fits, and best fit regressions were selected.

\section{RESULTS}

\subsection{Physiological characteristics at planting}

Storage factors such as temperature and duration, and stock type significantly influenced seedling water potential, RWC, the index of root growth (IRG) and needle (NEL) and root (REL) membrane integrity (Tab. I) as well as another physiological parameters such as gas exchange. Plant water status was drastically affected by storage conditions and duration. The value of water potential during storage decreased from $-0.53 \mathrm{MPa}$ in plants before storage $[27,28]$ to $-0.58 \mathrm{MPa}$ in $\mathrm{PR}$ plants stored for 1 day at $4{ }^{\circ} \mathrm{C}$, and to $-2.48 \mathrm{MPa}$ in $\mathrm{BR}$ seedlings stored for 15 days at $10^{\circ} \mathrm{C}$ (Tab. I).

The RWC of plants ranged between 80 and $90 \%$ in PR seedlings and between 58 and $90 \%$ in BR seedlings. Whereas in PR seedlings the RWC was significantly $(P<0.05)$ affected by duration but not by the temperature of storage, in BR seedlings there was also a significant $(P<0.05)$ difference between storage temperature after 15 days (Tab. I). Storage caused a significant increase in both needle (110-240\%) and root (13-45\%) electrolyte leakage compared to control plants (before storage)(Tab. I). The IRG was 5 when PR plants were stored for fewer than 15 days; lengthening storage to 15 days in both PR and BR seedlings diminished the index of root growth at 4.2 (PR seedlings at $4{ }^{\circ} \mathrm{C}$ ) and 2.0 (BR seedlings at $10^{\circ} \mathrm{C}$ ) (Tab. I).

Transpiration rates decreased between $27 \%$ and $41 \%$ in PR and BR seedlings, respectively, whereas WUE decreased about $19 \%$ in PR seedlings and 52\% in BR seedlings, after 15 days storage at $10^{\circ} \mathrm{C}(\mathrm{Tab} . \mathrm{I})$. All these data indicated that plants had suffered during storage, with BR seedlings being more sensitive to storage temperature than PR seedlings, and that these effects will determine their behaviour during the post-planting period if water availability is restricted.

\subsection{Post-planting performance}

Because these post-storage functional attributes may be altered in their expression after reforestation depending on environmental conditions in a phenomenon known as planting shock, we have analysed the post-planting expression of pine stock quality, summarized in Table I, under wet and drought regimes.

The water potential of plants planted under irrigation showed the typical post-planting stress syndrome (Fig. 1, left), which was significantly $(P<0.05)$ more remarkable in plants previosly stored at the highest $\left(10^{\circ} \mathrm{C}\right)$ temperature and without soil around the roots (BR seedlings). Water potential decreased progressively from the first to the 20th day after planting, and was dependent on the previous storage duration (Figs. 1A, 1C and $1 \mathrm{E}$ ). As noted above (Tab. I) an increase in temperature or duration of storage or the lack of soil around roots during this period exacerbated transplanting stress [13].

On the other hand, seedlings planted under non-irrigated regime for 20 days showed a significant $(P<0.05)$ and progressive reduction of water potential (Fig. 1, right). Values varied from $-1.74 \mathrm{MPa}$ in PR- and -2.18 MPa in BR-plants stored at $4{ }^{\circ} \mathrm{C}$ and $10^{\circ} \mathrm{C}$, respectively, for 1 day (Fig. 1B), to $-2.25 \mathrm{MPa}$ in PR- and -2.7 MPa in BR-plants stored at the same temperatures for 15 days (Fig. 1F). These values were $45 \%$ to $75 \%$ more negative than their counterparts planted under irrigated conditions. Again, significant differences $(P<0.05)$ between root cover and storage temperature were observed in planted seedlings in both well- and non-watered soils. However, the effect was ameliorated, at least partially, when rewatering occurred (Figs. 1B, 1D and 1F, recovery).

Unlike water potential, the RWC of seedlings was not significantly affected when planted under irrigated regime (data not shown); however, after 20 days without water, RWC was reduced in all seedlings. This effect was lower in PR plants than in BR plants. Rewatering for 6 days tended to enable seedlings subjected to different pre-planting conditions to recover RWC except, perhaps, for BR seedlings stored for a long time (15 days; data not shown). 


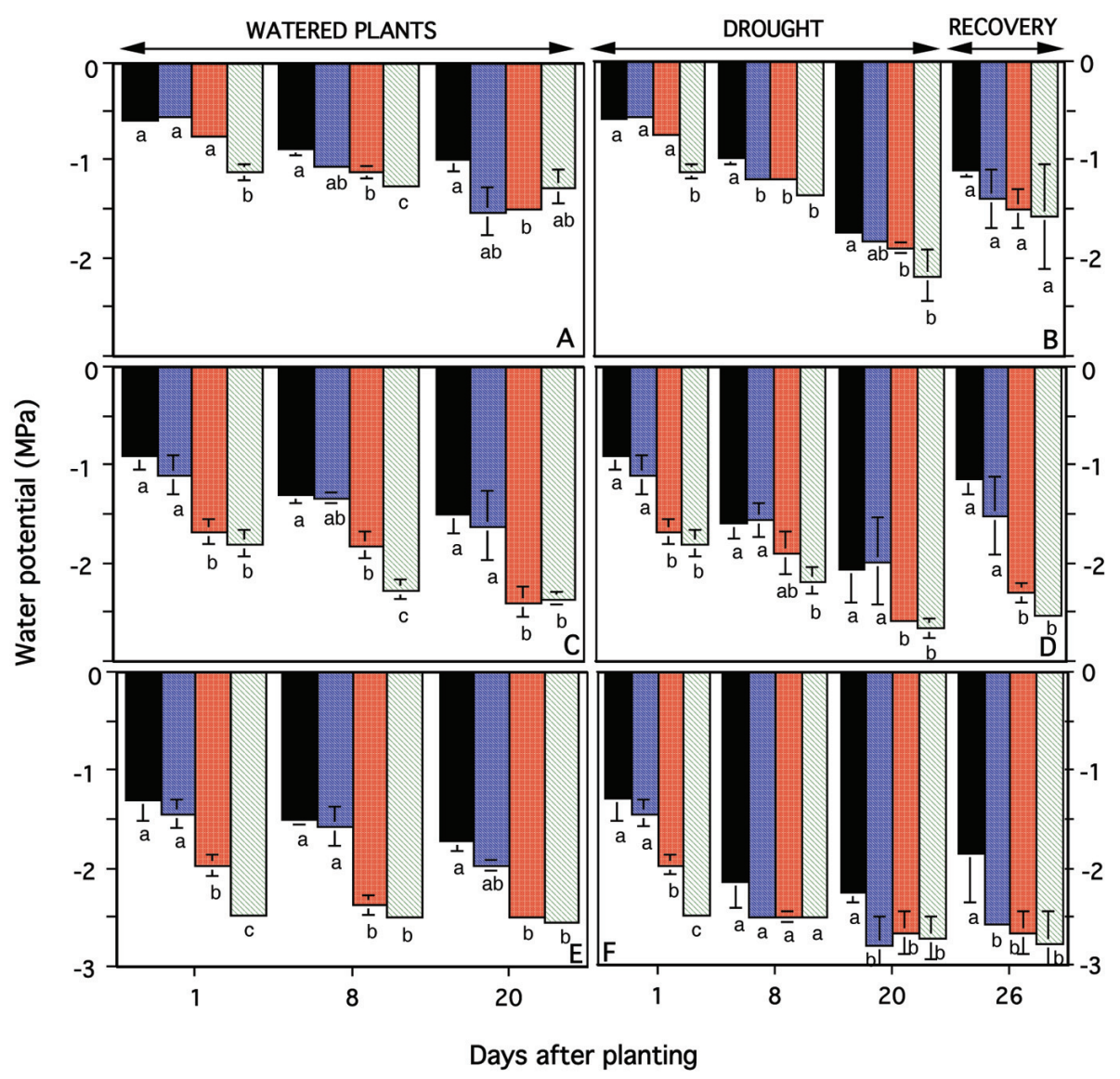

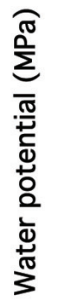

Figure 1. Time course of post-planting needle water potential of well-watered (left side) or water-stressed (right side: $d$ rought) radiata pine

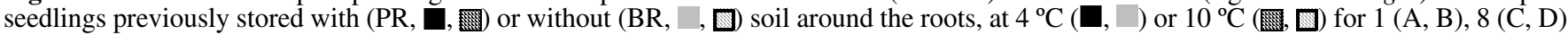
or 15 (E, F) days. Plants were rewatered (right side: recovery) after 20 days of water withholding. Each value represents the means $( \pm$ SE) of, at least, three independent experiments, each replicated twice. For a given storage period and postplanting day, mean values not sharing common letters are significantly different $(P<0.05)$.

Twenty days after planting we found a curvilinear relationship ( $r=0.897)$ between $\Psi_{W}$ and RWC (Fig. 2). When RWC declined between $90 \%$ and $70 \%$, the $\Psi_{\mathrm{W}}$ responded progressively, decreasing from $-1 \mathrm{MPa}$ to $-2.2 \mathrm{MPa}$. However, the $\Psi_{\mathrm{W}}$ dropped more slowly, up to $-2.8 \mathrm{MPa}$, with a further decrease of RWC to $25 \%$. This value seemed to be practically irreversible.

Figure 3 illustrates the changes in instantaneous transpiration rates over time, in both irrigated and non irrigated plants after planting. A post-planting shock effect was observed in this parameter (see left side of Fig. 3) which paralleled stomata closure (data not shown). Drought enhanced this depletion and 20 days after withholding water the depletion of transpiration reached values between $30 \%$ and $80 \%$ (see right side of Fig. 3) compared to non-stored plants. After rewatering, PR plants' transpiration reached values similar to those found in well watered plants. Only transpiration rates below $0.65 \mathrm{mmol} \mathrm{m}^{-2} \mathrm{~s}^{-1}$-values observed in BR-seedlings previously stored at $10^{\circ} \mathrm{C}$ - failed to reverse 6 days after rewatering (Fig. 3F).

Post-planting effects on root electrolyte leakage are depicted in Figure 4. In previous work [29] we showed significant

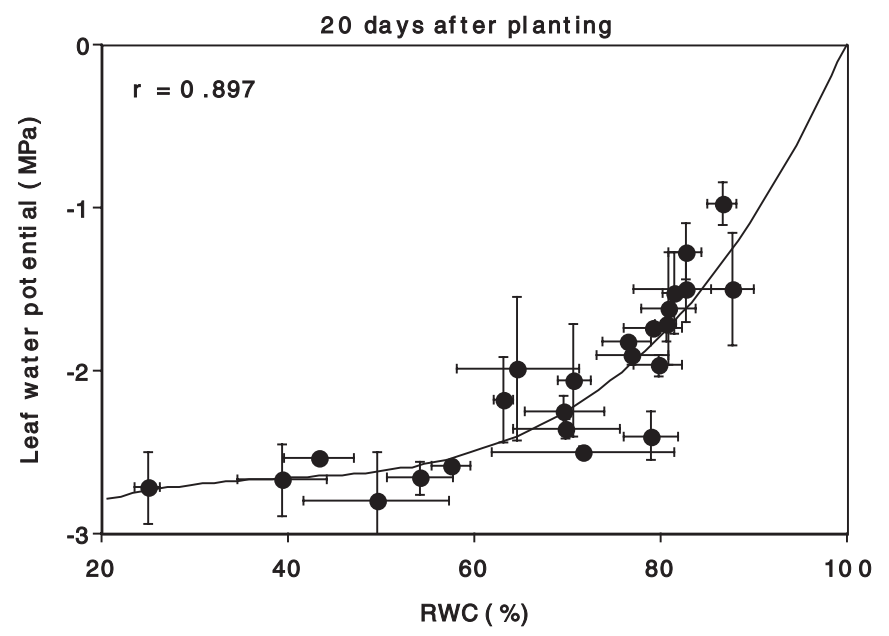

Figure 2. Correlation between RWC and leaf water potential (twenty days after planting) in radiata pine seedlings. Data were pooled through all storage conditions and post-planting watering regime. 


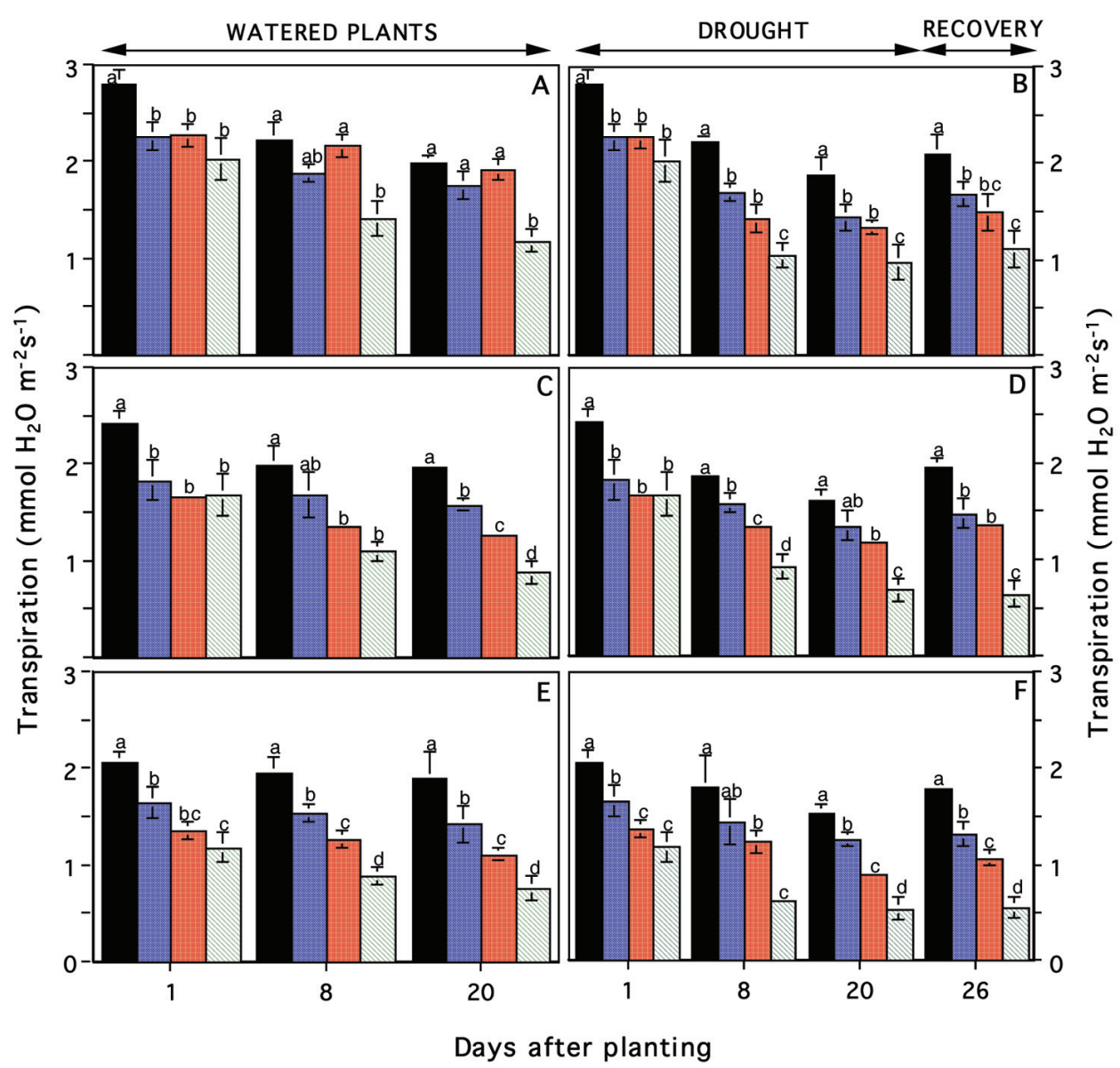

Figure 3. Time course of post-planting instantaneous water vapour loss of well-watered (left side) or water-stressed (right side: $d r o u g h t)$ radiata pine seedlings previously stored with (PR, $\square, \square)$ or without (BR, , $\square$ ) soil around the roots, at $4{ }^{\circ} \mathrm{C}(\boldsymbol{\square}, \square)$ or $10^{\circ} \mathrm{C}(\boldsymbol{\square}, \square)$ for $1(\mathrm{~A}, \mathrm{~B})$, $8(\mathrm{C}, \mathrm{D})$ or 15 (E, F) days. Plants were rewatered (right side: recovery) after 20 days of water withholding. Each value represents the means $( \pm$ SE) of, at least, three independent experiments, each replicated twice. For a given storage period and postplanting day, mean values not sharing common letters are significantly different $(P<0.05)$.

increase in root and needle electrolyte leakage during storage period (see Tab. I). Post-planting effects on electrolyte leakage depended on water regime and physiological characteristics of stock-type at planting time. Even in irrigated soils poor contact of roots with soil could limit water uptake and provoke injury (planting stress) to both roots (Fig. 4) and needles (data not shown), with the effect proving greater on needles than on roots. Thus, when plants stored for 15 days at $10^{\circ} \mathrm{C}$ were planted for 20 days in wet soil, root electrolyte leakage (REL) increased by $35 \%$ (Fig. 4E) whereas needle leakage increased by $55 \%$ (data not shown). If the post-planting was made under drought stress a dramatic increase in electrolyte leakage ocurred, amounting to $50 \%$ (Fig. $4 \mathrm{~F}$ ) in root and $195 \%$ in needle electrolyte leakage (data not shown). These increases in root and needle electrolyte leakage concur with results obtained in similar studies for various coniferous species [26].

Plant water status depends on the capability of roots to absorb water while REL is an indirect measure of root integrity. A close correlation $(r=0.892)$ between the RWC of seedlings and root integrity was observed 20 days after planting (Fig. 5).
When root electrolyte leakage exceeded $50 \%$ the seedlings' RWC dropped below $50 \%$. When root electrolyte leakage was higher than $60 \%$, the capacity of plants to recover their turgor after rewatering was irreversibly endangered (Fig. 5).

Growth chamber survival of radiata pine seedlings 2 months after transplanting under irrigated and non-irrigated regimes is represented in Figure 6. PR seedlings achieved at least $80 \%$ survival irrespective of storage temperature when planted under well irrigated conditions. Garriou et al. [12] also observed a good survival rate $(65-85 \%)$ in Corsican pine after planting seedlings under well-irrigated conditions. However, dry soils caused a remarkable drop in the survival figure, with mortality being temperature- and time of storage- dependent. $60 \%$ of PR seedlings survived when stored for 1 or 8 days at $4{ }^{\circ} \mathrm{C}$, and this percentage decreased to $15 \%$ after 15 days of storage (Fig. 6A).

At a higher storage temperature $\left(10^{\circ} \mathrm{C}\right)$ the effect of dry soils was even more drastic, resulting in survival rates of $40 \%$ for plants that had been stored for 1 day, $20 \%$ for plants stored for 8 days and as low as $0 \%$ for those kept 2 weeks in storage (Fig. 6B). The survival capacity of BR seedlings was more 


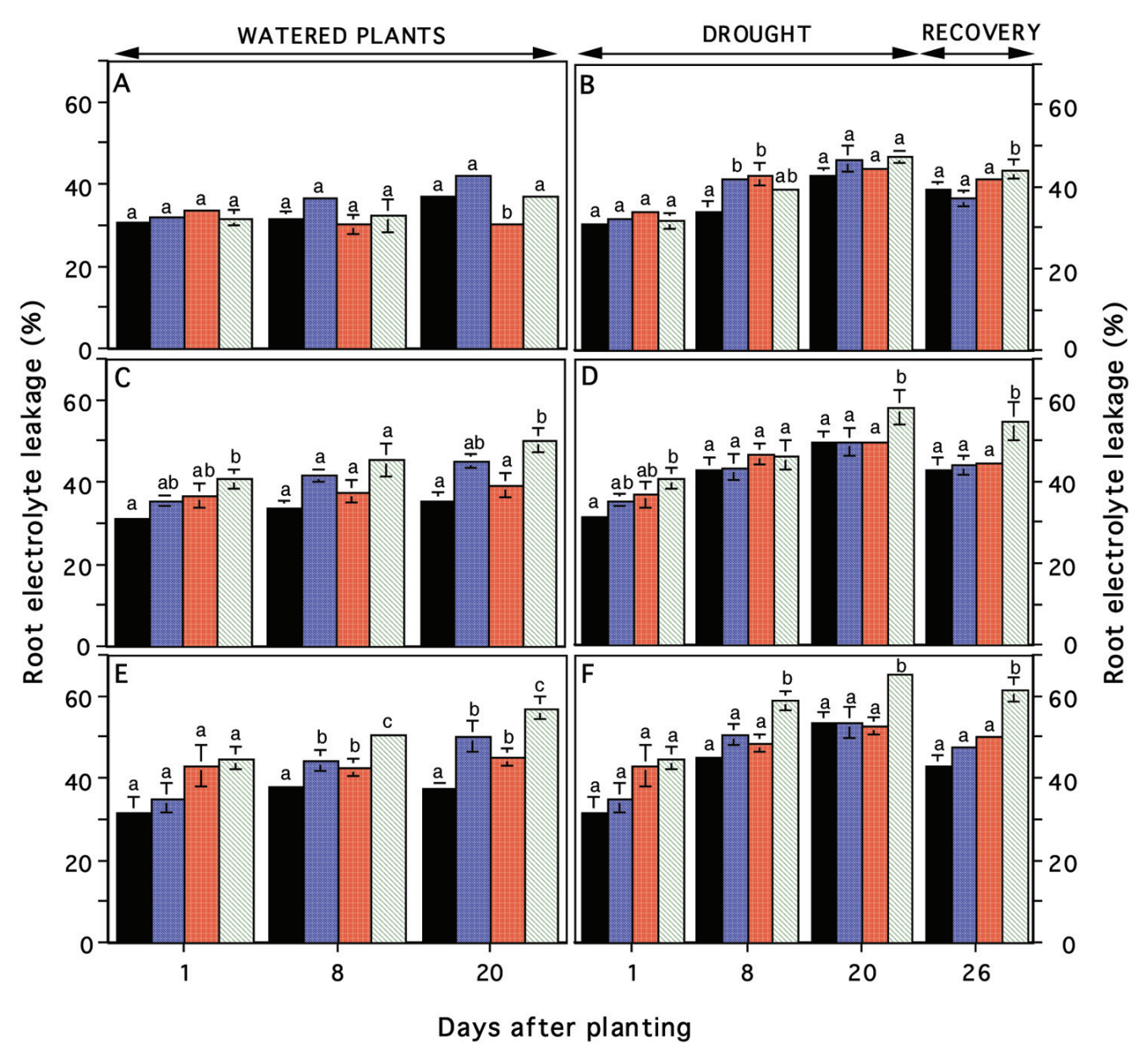

Figure 4. Time course of post-planting root electrolyte leakage of well-watered (left side) or water-stressed (right side: $d$ rought) radiata pine seedlings previously stored with (PR, $\mathbf{\square}, \mathbf{\square}$ ) or without (BR, , $\square$ ) soil around the roots, at $4{ }^{\circ} \mathrm{C}(\boldsymbol{\square}, \square)$ or $10^{\circ} \mathrm{C}(\boldsymbol{\square}, \square)$ for 1 (A, B), $8(\mathrm{C}, \mathrm{D})$ or 15 (E, F) days. Plants were rewatered (right side: recovery) after 20 days of water withholding. Each value represents the means $( \pm$ SE) of, at least, three independent experiments, each replicated twice. For a given storage period and postplanting day, mean values not sharing common letters are significantly different $(P<0.05)$.

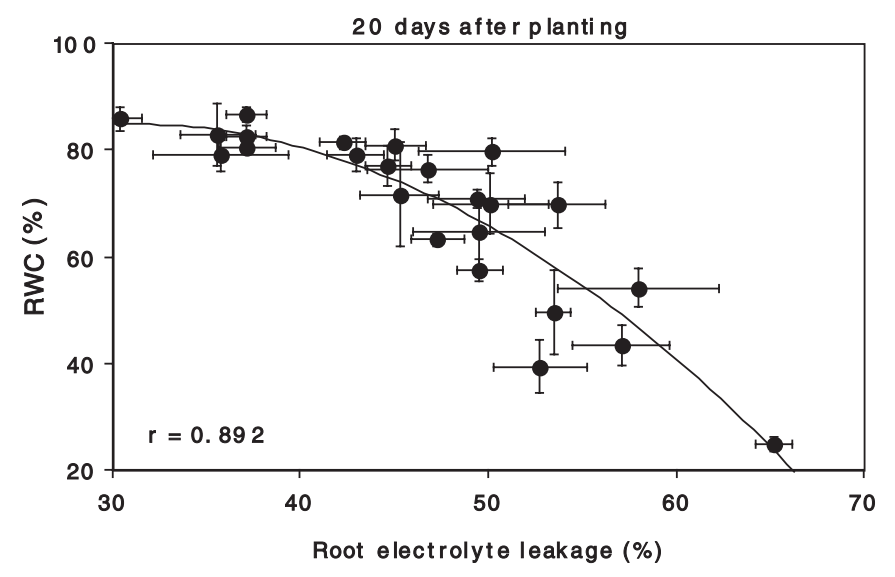

Figure 5. Correlation between RWC and root electrolyte leakage (twenty days after planting) in radiata pine seedlings. Data were pooled through all storage conditions and post-planting watering regime. affected than PR, and their mortality was also more pronounced when planted under water deficit conditions (Figs. 6C and 6D). One day of storage at $4{ }^{\circ} \mathrm{C}$ produced the death of $40 \%$ of plants planted in wet soils (Fig. 6C) and after 15 days at $4{ }^{\circ} \mathrm{C}$ or after 8 days at $10^{\circ} \mathrm{C}$ only $20 \%$ of BR seedlings survived. The percentage of BR plants that survived in drought conditions was $40 \%, 20 \%$ and $0 \%$ in seedlings taken from 1,8 or 15 days of storage at $4{ }^{\circ} \mathrm{C}$, respectively (Fig. 6C), and 30\%, $0 \%$ and $0 \%$ after the same storage periods at $10^{\circ} \mathrm{C}$ (Fig. 6D).

Although a close $(r=0.836)$ relationship between needle water potential and survival was observed two months after transplanting in the correlation analysis (data not shown), a slightly better fit ( $r=0.874)$ was found between survival and the RWC, measured 20 days after planting, when the mean values of both water regimes were considered (Fig. 7). As can be seen in Figure 7, the percentage of survival of radiate pine was greater than $50 \%$ when RWC was higher than $75 \%$, whereas when water content was lower than $50 \%$ the survival rate was practically nil. 


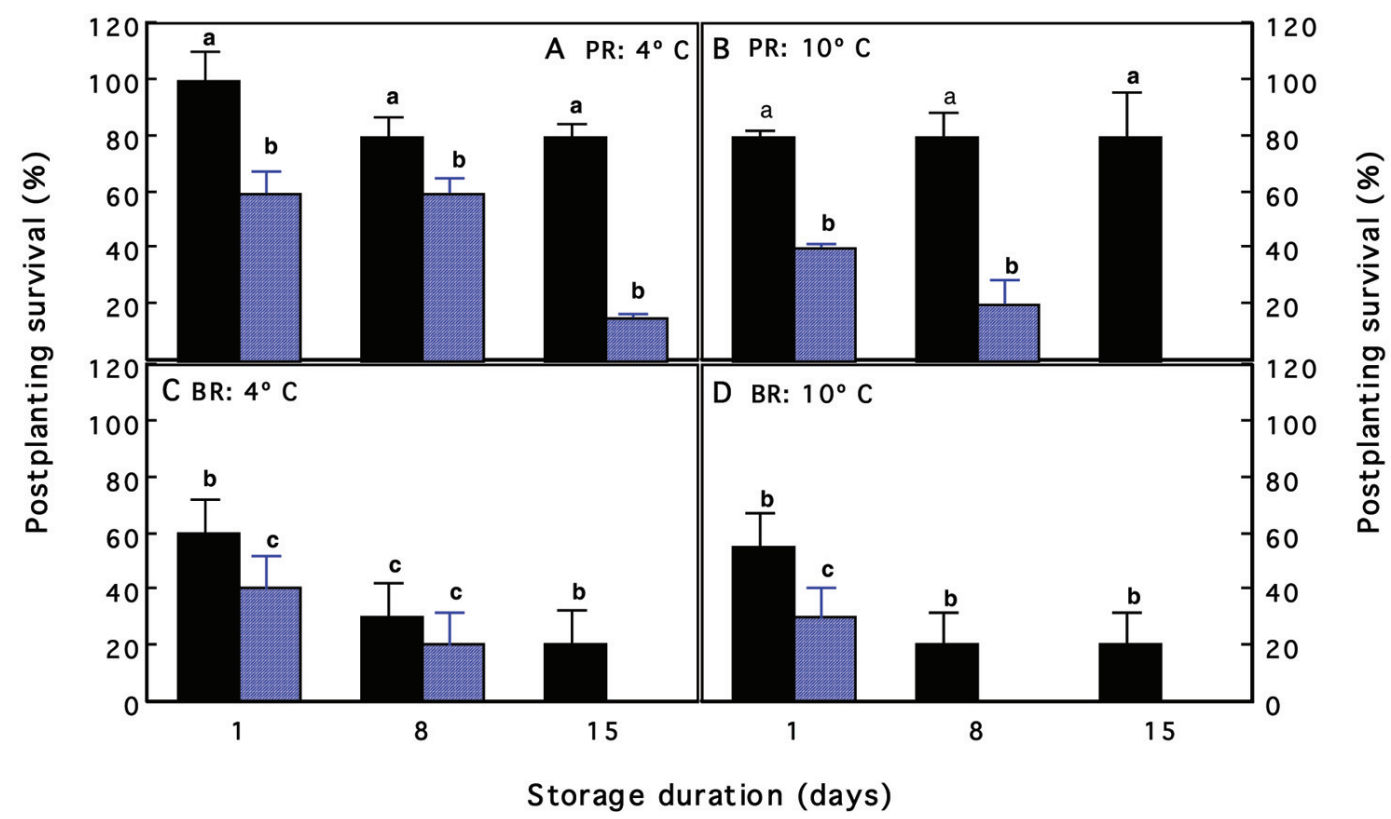

Figure 6. Post-planting survival (\%) of radiata pine seedlings previously stored with (PR) or without (BR) soil around the roots, for $1-15$ days at $4{ }^{\circ} \mathrm{C}(\mathrm{A}, \mathrm{C})$ or at $10{ }^{\circ} \mathrm{C}(\mathrm{B}, \mathrm{D})$. Seedlings were planted in wet $(\boldsymbol{\square})$ or drought $(\mathbb{O})$ soils. Each bar represents the means $( \pm \mathrm{SE})$ of three independent experiments, each replicated twice. For a given day, mean values not sharing common letters are significantly different $(P<0.05)$.

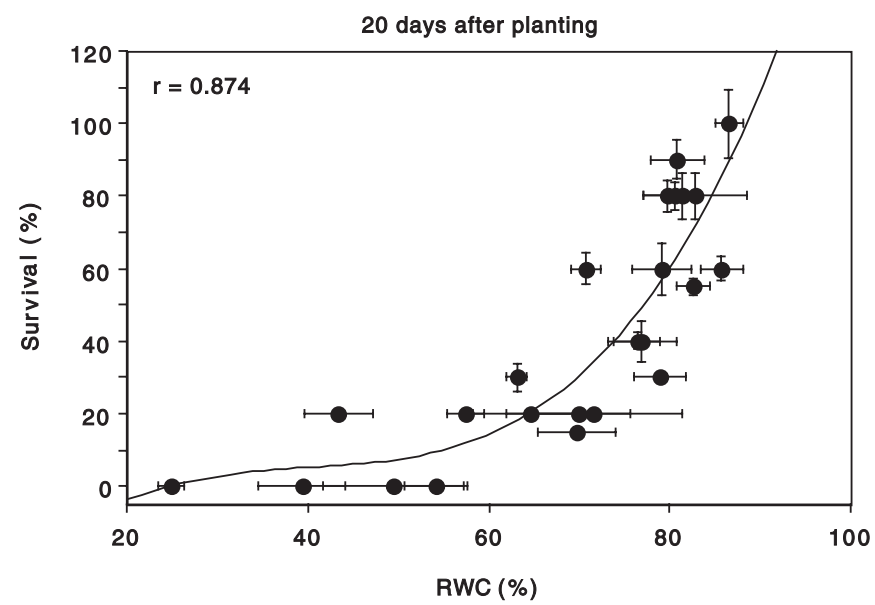

Figure 7. Correlation between the relative water content (RWC) after 20 days of planting and the plant survival percentage in radiata pine seedlings. Data from wet and drought regimes were pooled.

\section{DISCUSSION}

Several authors have observed that transplants remained water stressed for a long period of time even when soil water content was maintained at field capacity $[13,16,19]$. Plant water balance depends on soil moisture, root absorption capability and shoot transpiration rates. So, internal-water stress of plants occurs either from (1) excessive transpiration that can be caused by inadequate stomatal control as evaporative demand increases $[14,21]$ or (2) slow absorption of water from soil because of root confinement, poor contact of roots with soil, and low root system permeability [4, 14], or (3) a combination of both, which in turn adversely affects the survival and growth of plants.

Water potential is a good indicator of post-planting stress because when the absorption of water is insufficient to compensate loss by transpiration, the water potential of plant decreases. In our experiment, the results show that the transplants, even when regularly irrigated, suffer from planting shock, resulting in decreased water potential over the time of study (20 days, Fig. 1 left). These water potentials remains low even after stomatal conductance declined (data not shown). Similar results were observed in ponderosa pine by Omi et al. [34] who suggested that either low stomatal conductance did not sufficiently limit the water loss, or the water uptake rate was not enough to offset the loss $[14,36]$. The stress suffered by transplanted seedlings depends on the one hand upon the soil water at the time of planting (Fig. 1) [19], and on the other hand on previous history of stock types: root coverage, duration and temperature of storage, root growth potential (Tab. I), i.e. the rate at which new roots are regenerated [31], etc. When plants were not watered for 20 days after planting, the degree of water stress was greater (Fig. 1, right).

We have observed that in plants with $\Psi_{\mathrm{W}}$ lower than $-2.5 \mathrm{MPa}$ measured just before transplanting, the ability of radiata pine seedlings to initiate and elongate roots was drastically reduced [29]. The ability of seedlings to take up water depends on the efficiency with which they produce and elongate new roots at planting time. This RGP, expressed as an index of root growth [5], showed that BR radiata pine seedlings stored at $10^{\circ} \mathrm{C}$ for more than 8 days (Tab. I) reached values of 2 . A root growth index of 2 or lower is indicative of poor capacity to generate new roots after planting, resulting in unacceptable planting 
mortality rates (Fig. 6) [3, 38] as obtained in this work. Root regeneration, even under wet regime (see IRG in Tab. I), was probably limited by the reduction of photosynthesis at planting time [30] and the delay in reassuming photosynthetic capacity after planting (data not shown) as a consequence of water stress. This water stress also causes the loss of cell turgor which is required for root elongation. Moreover, the delay in reassuming photosynthetic capacity hinders the accumulation of solutes, which reduces the possibility of maintaining turgor and consequently jeopardizes the radiata pine seedlings' ability to tolerate drought stress [14] after planting. Osmotic adjustment is the main mechanism whereby tree species cope with drought [14].

If there is no root growth, xylem water potential declines and transplants will die. Moreover, Burdett [6] has suggested that root-soil contact of newly planted seedlings is usually poor and for this reason water is a limiting resource for seedling establishment and survival. The increased water stress after planting implies that interference with water uptake is the major factor that prevents the growth of new roots and leads to the death of plants $[14,39]$. In our study, the shortage of water uptake disturbed water status, reducing both water potential (Fig. 1) and the RWC (data not shown), and a curvilinear relationship ( $r=$ 0.897 ) between these two parameters was observed (Fig. 2).

Furthermore, the lowering of internal water status can cause severe injury to roots (Fig. 4). The reduction of root water content as a consequence of desiccation of the root system [9] is accompanied by a decrease of needle water potential [26] which in turn provokes electrolyte leakage in both roots (Fig. 4) and needles (data not shown). In addition, the decline in water potential provokes a stomatal response (data not shown) to decrease the transpiration rate (Fig. 3) and avoid water loss. Thus, although transpiration was reduced and the water loss may be alleviated by stomatal closure, the insufficient development and/or deterioration of the root system under non-irrigated regime (Fig. 4) enhanced the water stress of planting seedlings through lower water uptake and reduced ability to maintain turgor, establishing a close relationship between root membrane integrity and the water status of the plants (Fig. 5).

The lowering of osmotic potential due to net solute accumulation is a major component of drought resistance for woody, as well as herbaceous, plants, allowing them to maintain turgordependent processes such as cell expansion and stomatal aperture even at low water potential [33]. It has been claimed that pines are suited to dry habitats because they are able to increase water use efficiency under water stress. For example, osmoregulation has been shown in root tips of drought-resistant Pinus pinaster populations in Morocco [32], along with a high capacity for osmotic adjustment in needles of several genotypes of the same species [33], and a decrease in osmotic potential at full turgor also in the same maritime pine species [10]. However, no evidence of osmotic adjustment was detected by us in Pinus radiata seedlings subjected to both drought or acid rain [27]. Moreover, Picon-Cochard and Guehl [35] were unable to detect soluble carbohydrate accumulation in Pinus pinaster seedlings under water deficit, suggesting that insufficient duration or severity of applied water stress suppressed the expression of osmotic adjustment [33]. Coutts [9] and Sucoff et al. [39] reported that the root system in conifers is prone to desiccation, essentially, under the desiccating conditions such as those performed by us in which plants were stored in unsealed bags. However, when plants are kept in sealed plastic bags, the plants' water status remains constant and no alterations occurs $[9,12]$.

The likelihood of recovery under the different parameters analysed after rewatering depends on the conditions and period of storage such as root coverage and temperature (Tab. I), which may lead to a lag in their resumption or even to no recovery at all, as in the case of the BR seedlings stored for 15 days which did not survive when planted in dry soils (Fig. 6D). This inability to recover from transplanting shock may reflect impacts of transplanting on metabolic processes as was postulated by Guehl et al. [16]. In this respect, we observed a reduction in $\mathrm{CO}_{2}$ assimilation capacity (data not shown) which in turn can reduce root growth as mentioned above. The rate of physiological recovery is dependent on the severity of drought [14] but also on the conditions and duration of preplanting storage; as the storage period is lengthened the rate of water potential (Fig. 1, right) and transpiration (Fig. 3, right) recovery decreases after the seedlings are rewatered.

Thus, the water stress caused by insufficient water supply from soil to roots after planting, and insufficient stomatal control result in poor survival and slower growth $[3,23,36]$. This poor survival can be observed even when plants are planted in good water conditions (Fig. 6) [29]. When the $\Psi_{W}$ fall to values between $-1.75 \mathrm{MPa}$ and $-2.7 \mathrm{MPa}$, the possibility of surviving was reduced by 60 to $75 \%$, whereas $\Psi_{\mathrm{W}}$ lower than $-2.75 \mathrm{MPa}$ cancels any possibility. Similar results were obtained in different coniferous species subjected to various storage regimes and packaging methods $[12,13]$.

Our results show that a drop of RWC under $50 \%$ practically prevents the survival of seedlings (Fig. 7). This fact is not in accordance with results reported by Garriou et al. [12] who observed a reduction in survival and root growth potential despite the favourable water status of cold-stored Corsican pine. The close relationship observed between RWC and root electrolyte leakage (Fig. 5) suggested that REL after drought stress could be a good predictor of field performance as previously claimed by us [29] and several other authors [12, 25, 40].

Postplanting mortality increased as the storage period was extended indicating a loss of water stress resistance due to storage. It has been demonstrated that sugars and starch can be reduced during storage [7], and this reduction jeopardizes stress resistance and consequently post-planting survival [17]. McCracken [22] found evidence that this depletion was particularly noticeable in radiata pine seedlings during cold storage. The exhaustion of the energy reserves can reduce the ability of initiate and elongate new roots [30] (Tab. I) and consequently decreases root water uptake. Moreover, as reported by Coutts [9], exposure of roots to drying conditions before planting causes a rapid decrease in fine root development after planting, impairing water uptake and increasing water stress which in turn results in lower survival (Figs. 6 and 7).

Our findings show that performance and survival after planting may depend mainly on stock-type, both under well- and limited-water regimes, with BR seedlings performing much more poorly than PR ones. This finding has also been observed in several coniferous and non-coniferous tree species $[14,18]$ suggesting that development of the root system in BR seedlings after planting is lesser than in PR seedlings and thus they take 
up less water than needed to offset water loss by needles, and that cold-stored bare-root seedlings have a high resistance to water flow through the plant just after removal from cold storage $[8,15]$.

Our results also show that the success of planting must be attributed to the different environmental conditions following outplanting in addition to the post-storage physiological conditions of seedlings, that is, at pre-planting time. Thus, the ability of the plants' roots to supply water has a huge impact on the initial survival potential, as we have stated [30].

Finally, these findings clearly indicate that transplanting shock and the stress caused by drought seemed to be, although additive, transitory at least in plants stored at $4{ }^{\circ} \mathrm{C}$ with soil around roots (PR) which achieve survival rates $>60 \%$ (except seedlings stored for 15 days whose survival was only $20 \%$ ). PR seedlings stored at $10{ }^{\circ} \mathrm{C}$ or BR seedlings stored both at 4 or $10{ }^{\circ} \mathrm{C}$ for 15 days are not able to survive at all under drought conditions. These data also confirm our previous conclusions: storage of radiata pine seedlings at $10^{\circ} \mathrm{C}$ and humidity under $80 \%$ for 15 days is not recommended because such conditions reduce stock quality $[29,30]$ and post-planting survival, including under wet regime (these results). Moreover it is not recommended to store radiata pine seedlings for more than one week when planting is in drought regime even though seedlings roots are surrounded by soil (PR seedlings).

Acknowledgements: This research was financially supported by grant GV118.319-IDT4/93, grant UPV 118.30-G07/98 and grant MEC (DGESIC) PB98-0148. A.M.-P. was the recipient of a grant from Departamento de Agricultura y Pesca del Gobierno Vasco (Spain). We wish to thank Viveros Oihanberri, S.A. for kindly supplying pine seedlings and to D. Johnson for correcting the English text.

\section{REFERENCES}

[1] Balneaves J.M., Biological advantages of using the direct on-bed packing system in a droughty climate, in: Menzies M.I. (Ed.), Proceedings of the IUFRO, conference "Efficiency of Stand Establishment", Rotorua, New Zealand, September 1989, IUFRO, Rotorua, 1990.

[2] Bernier P.Y., Comparing natural and planted black spruce seedlings. I. Water relations and growth, Can. J. For. Res. 23 (1993) 2427-2434.

[3] Binder W.D., Scagel R.K., Krumlik G.J., Root growth potential: Facts, myths, value?, in: Proceedings, Combined Meeting of the Western Forest Nursery Association, USDA Gen. Tech. Rep. RM 167, 1988, pp. 111-118.

[4] Brissette J.C., Chambers J.L., Leaf water status and root system water flux in shortleaf pine (Pinus echinata Mill.) seedlings in relationship to new growth after transplanting, Tree Physiol. 11 (1992) 289-303.

[5] Burdett A.N., New methods for measuring root growth capacity: Their value in assessing lodgepine stock quality, Can. J. For. Res. 9 (1979) 63-67.

[6] Burdett A.N., Physiological processes in plantation establishment and the development of specifications for forest planting stock, Can. J. For. Res. 20 (1990) 415-427.

[7] Canell M.G.R., Tabbush P.M., Deans J.D., Hollingsworth M.K., Sheppard L.J., Philipson J.J., Murray M.B., Sitka spruce and Douglas-fir seedlings in the nursery and in cold storage: Root growth potential, carbohydrate content, dormancy, frost hardiness and mitotic index, Forestry 63 (1990) 9-27.
[8] Carlson W.C., Root system consideration in the quality of loblolly pine seedlings, South J. Appl. For. 10 (1986) 87-92.

[9] Coutts M.P., Leaf water potential and control of water loss in droughted Sitka spruce seedlings, J. Exp. Bot. 32 (1981) 1193-1201.

[10] Fernández M., Gil L., Pardos J.A., Response of Pinus pinaster Ait. Provenances at early age to water suply. I. Water relation parameters, Ann. For. Sci. 56 (1999) 179-187.

[11] Folk R.S., Grossnickle S.C., Determining field performance potential with the use of limiting environmental conditions, New For. 13 (1997) 121-138.

[12] Garriou D., Girard S., Guehl J.M., Généré B., Effect of desiccation during cold storage on planting stock quality and field performance in forest species, Ann. For. Sci. 57 (2000) 101-111.

[13] Girard S., Clement A., Cochard H., Boulet-Gercout B., Guehl J.M., Effects of desiccation on post-planting stress in bare-root Corsican pine seedlings, Tree Physiol. 17 (1997) 429-435.

[14] Grossnickle S.C., Ecophysiology of Northern spruce species. The performance of planted seedlings, NRC-CNRC Research Press, Ottawa, Canada, 2000.

[15] Grossnickle S.C., Blake T.J., Acclimation of cold-stored jack pine and white spruce seedlings: Effect of soil temperature on water relation patterns, Can. J. For. Res. 15 (1985) 544-550.

[16] Guehl J.M., Clement A., Kaushal P., Aussenac G., Planting stress, water status and non-structural carbohydrate concentration in Corsican pine seedlings, Tree Physiol. 12 (1993) 173-183.

[17] Jiang Y., McDonald E., Zwiazek J.J., Effects of cold storage and water stress on water relations and gas exchange of white spruce (Picea glauca) seedlings, Tree Physiol. 15 (1995) 267-273.

[18] Kaufmann M.R., Stomatal control and the development of water deficit in Engelman spruce seedlings during drought, Can. J. For. Res. 9 (1979) 297-304.

[19] Kaushall P., Aussenac G., Transplanting shock in Corsican pine and cedar of Atlas seedlings: Internal water deficits, growth and root regeneration, For. Ecol. Manage. 27 (1989) 29-40.

[20] Kozlowski T.T., Water supply and tree growth. I. Water deficits, For. Abstr. 43 (1982) 57-95.

[21] Livingston N.J., Black T.A., Water stress and survival of three species of conifer seedlings planted on a high elevation south-facing clear-cut, Can. J. For. Res. 17 (1987) 1115-1123.

[22] McCracken I.J., Packaging and cool storage of tree seedlings, N.Z. J. For. Sci. 24 (1979) 278-287.

[23] McCreary D.D., Duryea M.L., OSU vigor test, in: Duryea M.L. (Ed.), Principles, procedures and predictive ability, Evaluating Seedling Quality: Principles, procedures and predictive ability of major tests, Workshop: For. Res. Lab., Oregon State Univ, Corvailis, Oregon, 1985, pp. 85-92.

[24] McKay H.M., Electrolyte leakage from fine roots of conifer seedlings: A rapid index of plant vitality following cold storage, Can. J. For. Res. 22 (1992) 1371-1377.

[25] McKay H.M., A review of the effect of stresses between lifting and planting on nursery stock quality and performance, New For. 13 (1997) 369-399.

[26] McKay H.M., White I.M.S., Fine root electrolyte leakage and moisture content: Indices of Sitka spruce and Douglas-fir seedling performance after desiccation, New For. 13 (1997) 139-162.

[27] Mena-Petite A., Duñabeitia M.K., González-Moro B., MuñozRueda A., Lacuesta M., Sequential effects of acidic precipitation and drought on water relations of Pinus radiata seedlings, J. Plant Physiol. 155 (1999) 93-100.

[28] Mena-Petite A., González-Moro B., González-Murua C., Lacuesta M., Muñoz-Rueda A., Sequential effects of acidic precipitation and drought on photosynthesis and chlorophyll fluorescence parameters of Pinus radiata D. Don seedlings, J. Plant Physiol. 156 (2000) 84-92.

[29] Mena-Petite A., Ortega-Lasuen U., González-Moro B., Lacuesta M., Muñoz-Rueda A., Storage duration and temperature effect on the functional integrity of container and bare-root Pinus radiata D. Don stock types, Trees 15 (2001) 289-296. 
[30] Mena-Petite A., Robredo A., Alcalde S., Duñabeitia M.K., GonzálezMoro B., Lacuesta M., Muñoz-Rueda A., Gas exchange and chlorophyll fluorescence responses of Pinus radiata D. Don seedlings during and after several storage regimes and their effects on postplanting survival, Trees 17 (2003) 133-143.

[31] Nambiar E.K.S., Bowen G.D., Sands R., Root regeneration and plant water status of Pinus radiata D. Don seedlings transplanted to different soil temperatures, J. Exp. Bot. 30 (1979) 1119-1131.

[32] Nguyen A., Lamant A., Variation in growth and osmotic regulation of roots of water-stressed maritime pine (Pinus pinaster Ait.) provenances, Tree Physiol. 5 (1989) 123-133.

[33] Nguyen-Queyrens A., Costa P., Loustau D., Plomion C., Osmotic adjustment in Pinus pinaster cuttings in response to a soil drying cycle, Ann. For. Sci. 59 (2002) 795-799.

[34] Omi S.K., Yoder B., Rose R., Fall lifting and long-term freezer storage of ponderosa pine seedlings: Effects on post-storage leaf water potential, stomatal conductance, and root growth potential, Tree Physiol. 8 (1991) 315-325.

[35] Picon-Cochard C., Guehl J.M., Leaf gas exchange and carbohydrate concentrations in Pinus pinaster plants subjected ot elevated $\mathrm{CO}_{2}$ and a soil drying cycle, Ann. For. Sci. 56 (1999) 71-76.
[36] Sands R., Transplanting stress in radiata pine, Aust. For. Res. 14 (1984) 67-72.

[37] Scholander P.F., Hammel H.T., Bradstreet E.D., Hemmingsen E.A., Sap pressure in vascular plants, Science 148 (1965) 339-346.

[38] Simpson D.G., Vyse A., Thomson C.F., Roots growth effects on field performance, in: Proceedings, Combined Meeting of the Western Forest Nursery Associations, USDA For. Ser. Gen. Tech. Rep. RM-167, 1988, pp. 111-118.

[39] Sucoff E., Buschena C., Tamte P., Desiccation and water potentials in the roots, leaves, and shoots of bare-root red pine and white spruce, Can. J. For. Res. 15 (1985) 989-992.

[40] Symeonidou M.V., Buckley P.G., The effect of pre-planting desiccation on survival and growth of Prunus cerasifera seedlings and the relationship of physiological indicators at planting with field performance and survival, Russ. J. Plant Physiol. 44 (1997) 514 517.

[41] Tanaka Y., Brotherton P., Hosteter S., Chapman D., Dyce S., Balanger J., Johnson B., Duke S., The operational stock quality testing program at Weyerhaeuser, New For. 13 (1997) 423-437. 